\title{
Louis Cardinal Billot, S.J. (1846-1931): Thomist, Anti-Modernist, Integralist
}

\author{
PeterJ. Bernardi, S.J. \\ Theology Department, Loyola University, emeritus, Chicago, IL, USA \\ pbernardi@luc.edu
}

\begin{abstract}
Largely forgotten today, the French Jesuit Louis Billot was "the most important Thomistic speculative theologian of the late nineteenth century." He taught generations of students at the Pontifical Gregorian University during the pontificates of Leo XIII and Pius X. His neo-Scholastic manuals remained influential until the Second Vatican Council. Having made a major contribution to the church's anti-Modernist campaign, Billot was made a cardinal in 1910. He served on various Vatican congregations, including the Holy Office, during three pontificates. In the 1920s, Billot ran afoul of Pius $\mathrm{XI}$ for refusing to retract his support for the neo-monarchist, nationalist movement Action Française, led by the agnostic Charles Maurras, that had sought an alliance with French Catholics to defeat the anti-clerical Third Republic. Compelled to resign his cardinatial dignity, the only prelate in the twentieth century to incur this humiliation, Billot lived his last years in quiet retirement outside of Rome.
\end{abstract}

\section{Keywords}

Thomistic Revival - neo-Scholasticism - Modernism - Jesuit cardinal - Action Française - integralism - anti-Liberalism - Society of Jesus

"Aliam praeterea iacturam, eamque haud ita levem, tum fecit amplissimus Ordo vester, cum sacra se Purpura abdicavit eminentissimus ille vir, Ludovicus Billot." On December 19, 1927, Pope Pius XI officially announced to the curial cardinals gathered in secret consistory "the heavy loss suffered by the Sacred College on 
account of the renunciation of the Purple by the most eminent Louis Billot." After having served sixteen years as a cardinal in the Roman Curia, Louis Billot returned to the state of a simple religious of the Society of Jesus. The resignation had actually occurred on September 13. The irony was not lost on observers-five years earlier, Cardinal Billot had placed the papal tiara on the head of the newly elected Pope Pius XI (r.1922-39). The resignation of a "prince" of the church is a rare occurrence. Indeed, Billot was the only cardinal to have resigned in the twentieth century. Official accounts of the time did not tell the whole story; the circumstances of his resignation will be treated below.

\section{Overview of Louis Billot's Life}

Louis Maria Billot was born on January 12, 1846, at Sierck-les-Bains, in the diocese of Metz, a commune in the Moselle department (Lorraine) in northeastern France, which borders on Germany and Luxembourg. ${ }^{2}$ He was the eldest of seven children whose father was a customs officer. His brother Gabriel also became a Jesuit and was renowned for his preaching. ${ }^{3}$ Another brother served as a military commander in the First World War. ${ }^{4}$ Louis grew up during the Second Empire (1852-70) and attended Jesuit colleges that flourished during that era. ${ }^{5}$ After having studied theology at the major diocesan seminary of Blois, staffed by the Jesuits, Louis was ordained a priest on May 22, 1869. Six months later, he entered the Jesuit novitiate at Angers. ${ }^{6}$ Following

1 The pope added that "in the letter that he wrote to us in his own hand to ask our permission to resign his high dignity, the reasons which he invoked were of such a grand nobility in our eyes, of such a supernatural character and advanced for such important motives, that after long reflection and prayer before God, we have thought it possible to accept this renunciation." Acta Apostolicae Sedis [hereafter AAS], 19 (December 22, 1927): 437-39, here 438. Billot had not been ordained a bishop and thus returned to the status of a "simple religious."

2 A critical biography of Billot has yet to be written. A hagiographical monograph Le Cardinal Billot, lumière de la théologie (Paris: Beauchesne, 1947) was composed by Henri Le Floch, S.Sp., the longtime superior of the French National Seminary in Rome, and an ally of Billot.

3 Gabriel Billot (1847-1910). He entered the Jesuit order in 1871 and perished in a shipwreck.

4 See "Notae et Miscellanea: Le R.P. Louis Billot," Ephemerides theologicae Lovanienses 9 (1932): 292-95.

5 Billot attended the Jesuit colleges in Metz and Bordeaux. The classic study of the French Jesuit colleges is John W. Padberg's Colleges in Controversy: The Jesuit Schools in France from Revival to Suppression, 1815-1880 (Cambridge, MA: Harvard University Press, 1969).

6 One of his novitiate classmates was Emmanuel Barbier (1851-1925). After the Society of Jesus was expelled from France in 1901, Barbier was incardinated as a diocesan priest. Known for his extreme anti-liberalism, he founded the journal Critique du libéralisme religieux, politique, social (1908) for which he served as editor until 1914. Barbier and Billot shared an "anti-liberal" mentality. 
completion of the two-year novitiate and profession of first vows (poverty, chastity, and obedience) in the Society of Jesus, Billot was appointed to teach Sacred Scripture at Laval $\left(1871^{-75}\right)$ and then assigned to preaching ministry in Paris (1875-78) and Laval (1878-79). In 1879, he inaugurated a chair of dogmatic theology at the Catholic University of Angers. Three years later, Billot was missioned to teach young Jesuits at the recently opened scholasticate of St. Hélier on the English Channel island of Jersey. ${ }^{7}$ Billot professed his final vows there on February 2, 1883. His brief teaching stint at Jersey was not without tensions since he was strongly committed to the direct study of Thomas Aquinas (1224/25-74) and disdained Thomas's Scholastic commentators such as the Jesuit Francisco Suárez (1548-1617), whose writings were held in high esteem at Jersey. In 1885, Billot was summoned to Rome in keeping with Pope Leo XIII's (r.1878-1903) program to promote the renewal of the philosophy and theology of Aquinas in seminary teaching. ${ }^{8}$ Not yet forty years old, he was given the chair of dogmatic theology that had been occupied by such illustrious Jesuit predecessors as Giovanni Perrone (1794-1876) and Johann Baptist Franzelin (1816-86). ${ }^{9}$ Excepting an interlude of preaching ministry in Paris (1886-87), Billot taught dogmatic theology at the Gregorian University, the leading center of international seminary education, until 1910. In 1909, Pope Pius x (r.19o3-14) appointed Billot to the powerful Congregation of the Holy Office. Distinguished for his teaching, his numerous publications, and service to the Roman Curia as a trenchant anti-modernist, Billot was named a cardinal by Pope Pius X in $1911 .^{10}$ In 1923 , under Pius XI, he was named to the Biblical Commission that was warily monitoring biblical scholarship. These official responsibilities ceased when he resigned his cardinatial dignity in 1927 and

7 For a description of the circumstances under which the French Jesuits established themselves on this British possession located in the English Channel, see J. Walshe, S.J., "The Society in Exile at Jersey," Woodstock Letters 35 (1906): 83-9o. In 188o, the schools of the French Jesuits had been forced into exile by the anti-clerical Third Republic that especially targeted the Jesuit order. For a treatment of the animus towards the Society of Jesus in nineteenth-century French politics, see Geoffrey Cubitt, The Jesuit Myth: Conspiracy Theory and Politics in Nineteenth-Century France (Oxford: Clarendon Press, 1993).

8 Pope Leo's first encyclical Aeterni Patris (1879) [subtitle: "On the Restoration of Christian Philosophy in Catholic Schools in the Spirit of the Angelic Doctor, St. Thomas Aquinas"] had prescribed the study and teaching of Thomism.

9 See Bernhard Knorn, S.J, "Johann Baptist Franzelin (1816-86): A Jesuit Cardinal Shaping the Official Teaching of the Church at the Time of the First Vatican Council," Journal of Jesuit Studies 7 (2020): 592-615.

10 Billot was named the titular cardinal-deacon of Santa Maria in Via Lata. He participated in two papal conclaves: in 1914, the conclave elected Giacomo della Chiesa who became Pope Benedict XV; in 1922, the conclave elected Achille Ratti who became Pope Pius XI. 
retired to the Jesuit novitiate at Galloro (Ariccia), outside of Rome. He died there on December 18, 1931.

\section{Contextualizing the Life and Achievements of Louis Billot}

My exposition will consider Billot's life and achievements under three interrelated rubrics: his career as a Thomistic theologian, his role in the Modernist crisis that rocked the church in the early twentieth century, and his support for Action Française, the French politico-cultural party that garnered significant Catholic support until its peremptory condemnation by Pope Pius XI in 1926 . To appreciate the interrelated nature of these three foci, I will briefly sketch the larger cultural, political, and ecclesial contexts that shaped Billot's mentality.

In keeping with church's official position in the nineteenth century, Billot was an intransigent opponent of a "modernity" identified with liberal individualism and Enlightenment rationalism that was often explicitly at odds with the Roman Catholic Church, its teachings, and traditions. The Protestant Reformation, the French Revolution, modern philosophies, and growing secularism had fragilized the church's public standing, beliefs, and practices. ${ }^{11}$ Furthermore, modern scientific and historical advances called into question the understanding of biblical revelation and the church's doctrines. To resist these threats, the church sought to strengthen and renew its institutional authority and intellectual tradition, notably through the promulgation of the dogma of papal infallibility at the First Vatican Council (1869-70) and the

11 Joseph Komonchak has described the church's mentality in response to these modern developments: "The Catholic Church believed itself to be engaged in a great battle. The political and religious disruptions of the French Revolution and the Napoleonic era were interpreted as only the most visible and violent manifestations of an assault upon Catholic truths and values which had been initiated during the Reformation. That event was the first moment in a diabolical lineage that ran on through the Enlightenment and the French Revolution and was now, in the nineteenth century, bearing its latest and bitterest fruits in liberalism, socialism and communism. This was [...] great single rationalistic system that displayed itself first in theology and then, successively and cumulatively, in philosophy, politics and society. This rationalism was the great enemy of the Church and of the faith. Its essence was the repudiation of authority and tradition, the self-proclaimed independence or autonomy believed to be enshrined in Luther's private judgement and in Kant's definition of Enlightenment." See "Modernity and the Construction of Roman Catholicism," Cristianismo nella storia 18 (1997): 353-85, here 357-58. The "Syllabus of Errors" issued by the Holy See under Pope Pius IX in 1864 condemned the proposition that "The Roman Pontiff can, and ought to, reconcile himself, and come to terms with progress, liberalism and modern civilization." 
renewal of Thomism officially sanctioned by Pope Leo. ${ }^{12}$ In France, the polarization of mentalities became particularly acute in the late nineteenth century and early twentieth centuries when the aggressively anti-clerical Third Republic (1870-1940) approved measures that secularized education (1880), expelled the Jesuit order and other religious congregations (1880; 1901), and enacted the separation of church and state (1905). Billot's theological, ecclesial, and political stances must be understood in response to these developments.

\section{Greatest Thomist Theologian of His Time}

Shortly after his death, Louis Billot was saluted as "one of the greatest, perhaps from certain points of view, the greatest theologian of modern times."13 More recently, the British Dominican Fergus Kerr described Billot as "the greatest of the Jesuit theologians in Rome from 1885 onwards." ${ }^{14}$ Gerald McCool, an historian of neo-Scholasticism, described Billot as "the first really distinguished Neo-Scholastic theologian to be appointed to the Gregorian"15 and "a brilliant metaphysician who possessed an extensive and profound knowledge of St. Thomas [...], the first of the great Thomistic speculative theologians." ${ }^{\prime 16}$ Thomist "by conviction, and not by conscription," Billot played a significant role in the early decades of the Leonine revival of Thomism. ${ }^{17}$ His many publications were largely textbook commentaries on Aquinas's Summa theologica, composed in the "thesis" style of the Latin-language manuals. Based on his courses, which followed a three-year cycle of dogmatic topics, they constitute a complete set of treatises on the incarnation, the sacraments, personal sin,

12 For a sketch of the church's response to these threats, see John O'Malley, "The Long Nineteenth Century," in What Happened at Vatican II (Cambridge, MA: Harvard University Press, 2008): 53-92.

13 Bulletin thomiste 3 (1932): 457-59, here 457.

14 Fergus Kerr, "Recent Thomistica IV," New Blackfriars 87 (2006): 651-59, here 655. See also William V. Bangert, S.J., A History of the Society of Jesus (St. Louis, MO: Institute of Jesuit Sources, 1972), 448.

15 Gerald A. McCool, S.J., From Unity to Pluralism: The Internal Evolution of Thomism (New York: Fordham University Press, 1989), 33.

16 Gerald A. McCool, S.J., Nineteenth-Century Scholasticism: The Search for a Unitary Method (New York: Fordham University Press, 2007), 239. Billot was appointed to the prestigious Roman Academy of St. Thomas.

17 Gabriel Daly, Transcendence and Immanence: A Study in Catholic Modernism and Integralism (Oxford: Clarendon Press, 1980), 15. For a more detailed treatment of Billot's role in the Thomistic Revival, see Oliver Rafferty, S.J., "The Thomistic Revival and the Relationship between the Jesuits and the Papacy 1878-1914," Theological Studies 75 (2014): 746-73, at 752$53,757-58$, and $766-68$. 
God, the Trinity, the church, the infused virtues, the last things, Biblical inspiration, sacred tradition, original sin, and grace. ${ }^{18} \mathrm{He}$ also published several articles in the Gregorianum journal. His two most reprinted works were De verbo incarnato and De ecclesia. ${ }^{19}$ His Deo Uno et Trino was reprinted five years before the opening of Vatican II. Paul Duclos described Billot's achievement in these terms:

The vigorous style of his treatises is a good Latin at the service of a genuine power of reflection; his theological intuition generates arguments and objections in an irresistible logic and in the end Revelation comes to illuminate metaphysics. Too personal to be scholarly (erudito), at times he forces the texts and deforms the thought of his adversaries. The treatment of the Trinity offers a subtle, yet excellent, analysis of the concept of relations, and concerning the Mass, he develops a theory according to which the sacrifice ought to be understood as essentially a mystical immolation. ${ }^{20}$

While serving as a curial cardinal, following retirement from his Gregorian professorship, Billot published two series of ten articles each in the French Jesuit periodical Études. The first series (1917-19) treated the concept of the parousia, rebutting the modernist view that the early church's faith in the second coming of Christ was an illusion. ${ }^{21}$ The second series (1919-25) treated the question of divine providence and the salvation of the unbaptized (the "infidels"). Billot

18 The Latin titles of these manuals with the date of their initial publication: De Verbo Incarnato (Rome: PUG, 1892); De sacramentis, 2 vols. (Rome: PUG, 1893-95); De peccato personali (Rome: PUG, 1894); De Deo uno et trino (Rome: PUG, 1895); De Ecclesia Christi, 2 vols. (Rome: PUG, 1898-1910); De virtutibus infusis (Rome: PUG, 1901); De novissimis (Rome: PUG, 1902); De inspiratione Sacrae Scripturae (Rome: PUG, 1903); De sacra traditione (Rome: PUG, 1904); De peccato originali (Rome: PUG, 1910); and De gratia Christi (Rome: PUG, 1912; completed in 1921). Many of these manuals went through multiple editions and continued to be used as textbooks after Billot's retirement in 1910.

19 De Verbo Incarnato, 8th ed., 1949; De Ecclesia, 5th ed., 1927.

20 P. Duclos, "Billot, Louis," in Diccionario histórico de la Compañía de Jesús: Biográficotemático [hereafter $D H C J$ ], ed. Charles E. O'Neill and Joaquín María Domínguez, 4 vols. (Rome: Institutum Historicum Societatis Jesu, 2001), 1:45o. Unless indicated otherwise, the translations are my own. For a recent, appreciative exposition of Billot's theology of sacramental sacrifice, see Romanus Cessario, O.P., "Sacrifice, Social and Sacramental: The Witness of Louis Billot, S.J.," Nova et vetera (English edition) 14 (2016): 139-49.

21 These articles were subsequently published as the monograph La Parousie (Paris: Beauchesne, 1920). Billot concluded his book on an ominous note, indicating precursory signs of the catastrophic end foretold by the apocalyptic passages in the synoptic gospels and the Book of Revelation. 
magnanimously proposed that the majority of adults who have ever lived never attained true moral adulthood. Consequently, as with unbaptized infants, he concluded that their eternal destiny is limbo. Billot's thesis was not generally accepted by his theological peers. ${ }^{22}$

Billot had a profound influence on generations of students, among whom many became high-ranking ecclesiastics. ${ }^{23}$ The influence of his teachings was also magnified by his widely used textbooks and by the presence of his students in a great number of seminaries and scholasticates throughout the world. ${ }^{24}$ Three eminent scholars have offered convergent assessments of Billot's theological achievement. Edgar Hocedez, S.J. (1877-1948), author of a multi-volume study of nineteenth-century theology, wrote:

Of all the Jesuit theologians in the 19th century, Jean-Baptist Franzelin was the most celebrated and the most followed [...]. Fr. Billot contrasts with Cardinal Franzelin. The latter's method was historically based; Billot was above all speculative and a metaphysician. He moved easily and tirelessly in the highest abstractions, excelled and delighted in the analysis of concepts and fearlessly pushed principles to their ultimate consequences. He possessed the gift of synthesis to a rare degree, the art of reducing a treatise to a few philosophical principles. One could almost say of his treatise on the Trinity (De Deo Uno et Trino, 1895), his masterwork, that it is a metaphysical poem, the poem of the "Relation." On the other hand, the positive part is weak; it seems that he is scarcely interested in this department of the sacred sciences, and history and its methods are outside of his purview. His philosophy is rigorously Thomistic; nevertheless his interpretation of the angelic doctor is personal; he does not pay heed to what others could say about St. Thomas; he wanted to understand and follow the saint doctor himself; therefore several of his views have been contested by other Thomists. He possessed a remarkably clear style, a sure and potent pedagogical method: he understood the force of intrepid

22 See, for example, Louis Capéran, Le problème du salut des infidèles (Toulouse: Grand séminaire, 1934), 512-31.

23 In his allocution on the occasion of the fourth centenary of the Gregorian University, Pope Pius XII (r.1939-58) singled out Louis Billot for commendation. See AAS 45 (1953): 689-9o.

24 Giacomo Martina, "Grégorienne (Université)," Dictionnaire d'histoire et de géographie ecclésiastiques, 31 vols. (Paris: Letouzey et Ane, 1988), 22:cols. 81-88. "In 189o, of the 781 students studying at the Gregorian University, there were 237 Italians, 139 French, 130 Germans, 83 Americans, 49 English, 29 Swiss, and 29 Polish." Cited in Edward Baring, Converts to the Real: Catholicism and the Making of Continental Philosophy (Cambridge, MA: Harvard University Press, 2019), 27. 
affirmation and especially repeated under diverse forms which instilled fundamental ideas in [his students'] minds. With his faults and virtues, he exercised a profound influence, although more limited than Franzelin's; but most of his former students have kept an indelible memory of him. ${ }^{25}$

The French Jesuit historian of dogma Bernard Sesboüé (b.1929) has written that Billot's

speculative power is real, likewise the art of synthesis is capable of reducing an ensemble to a few metaphysical principles; it is undoubtedly superior to that of his predecessor Franzelin, [who was] more positive [in the sense of more historical] and put in service of a great power of reasoning which marshals arguments and objections according to a logic which aspires to be apodictic. The climate is very intellectualist. The strength of conviction can go so far as to force the meaning of texts and to assail adversaries in a massive and unilateral manner (without hesitation accused of 'absurdities,' of 'incoherences,' of 'illogicisms."'26

Sesboüé concludes that Billot had scant appreciation for positive research (exegesis and tradition) that he distrusted and which held a minimal place in his courses, except as the target of his polemics.

Dominican theologian Marie-Dominique Chenu (1895-1990), who was a seminarian in Rome during the Billot era, recalled that

Billot, whose works I studied much at this time [1913-20], was a theologian of great stature, but he was enclosed in one sector of theology, proudly ignorant of the others. Confined in one area, he became sectarian, in the etymological sense of the word. He was very intelligent, but his intellectualism made him very little sensitive to the irrational ways of the mystery

25 Edgar Hocedez, Histoire de la theologie au XIX siecle, 3 vols. (Paris: Desclée de Brouwer, 1947), 3:70-71. Although Pope Leo's encyclical Aeterni Patris had not proscribed the study of the Scholastic commentators on St. Thomas such as Suárez, Billot had no use for these "recentiores," his term for the modern doctors. Jacques Maritain (1882-1973) recalled a 1918 meeting with Billot in Rome during which the cardinal "blasts the adversaries of St. Thomas, says much evil about the Jesuits, attacks Suárez and Cajetan, and displays much bitterness.” Notebooks, trans. Joseph W. Evans (Magi Books: Albany, NY, 1984), 94.

26 Dictionnaire du monde religieux dans la France contemporaine, vol. 9: "Les Sciences religieuses: Le xix siècle, 1800-1914, sous la direction de François Laplanche” (Paris: Beauchesne, 1996), 63 . 
of faith. He enunciated the mystery in a purely intellectual articulation, beyond all personal experience. With that, he was completely foreign to the results of history: he did not accept that the ensemble of theology was tied to history [...]. The theology of Billot was totally ignorant of and disregarding of the historicity of the Christian economy, without familiarity with the Biblical sources, elaborated outside of the pastoral experience of the Church, and even more of the Christian people. It implied, at bottom, a theology of the faith entirely defined by conceptual and juridical authority, with no methodological guidance from the Mystery, which is nevertheless its object [...]. It was theology as ideology. ${ }^{27}$

Chenu added that "for as much as he was a Thomist, Cardinal Billot [...] was integralist, intellectualist, and authoritarian." ${ }^{28}$ I will return to this assessment below.

Billot's intellectual virtues and shortcomings did not go unremarked by his Jesuit contemporaries. In a highly laudatory essay on the occasion of Billot receiving the red hat in 1911, French Jesuit Jules Lebreton (1873-1956), professor of early Christianity at the Institut Catholique in Paris, while praising Billot as a speculative theologian, expressed regret that Billot's metaphysics "had neglected to make contact with contemporary philosophy, and, more particularly, with religious psychology" and stated that Billot's work was insufficiently informed by positive theology, especially the Patristic sources. ${ }^{29}$ Some years later, in a personal letter to Lebreton after the publication of the first volume of Lebreton's historical study of the dogma of the Trinity, Billot wrote:

You have made me understand one thing that had never entered my mind, to wit, what one can draw from historical theology, from the point of view that alone must interest us, after all, that of the ever more profound penetration of the truths that it pleased God our Lord to reveal to us. I was imbued with the prejudice that that was only an instrument of

27 Jacques Duquesne interroge le Père Chenu (Paris: Le Centurion, 1975), 30-31.

28 Jacques Duquesne interroge le Père Chenu, 44.

29 Jules Lebreton, "Son Éminence Le Cardinal Billot," Études 129 (1911): 514-25, here 521-23. McCool remarks: "[Billot] was exclusively a scholastic speculative theologian. Brilliant and influential though he was, he had practically no interest in history, and his writings are distinguished by a positive disregard for it. The result of his domination of the faculty unfortunately was that in the last years of the century, at a time when historical studies, especially in Germany, were raising serious problems for the Catholic faith, positive theology went into a serious decline at the Gregorian" (From Unity to Pluralism, 33). 
demolition rather than edification. I have now shaken off that prejudice, and it is to you that I owe this." 30

While Billot's response to Lebreton showed a new openness to the value of historical theology, it fell short of appreciating the kind of historical contextualization and development of doctrine associated with the writings of John Henry Newman (1801-9o) and Étienne Gilson (1884-1978).

On July 24, 1914, the Sacred Congregation for Studies published the "TwentyFour Thomistic Theses," an authoritative compendium of principles and important teachings of St. Thomas, in order to regulate the teaching of St. Thomas in seminary education. ${ }^{31}$ Guido Mattiussi, S.J. (1852-1925), who had succeeded to Billot's professorial chair at the Gregorian, was the primary drafter, with Billot exercising some oversight. Since Pope Leo's encyclical Aeterni Patris, what counted as Thomism had been a bone of contention between the neoThomists and the Suarezians within the Society of Jesus. Billot's insistence on the study of St. Thomas himself, without relying on his Scholastic interpreters, resulted in tensions within the Jesuit order. Billot considered Superior General Franz-Xaver Wernz (in office 1906-14) to be non-compliant with Rome's directives that prescribed the works and teachings of St. Thomas. ${ }^{32}$

\section{$4 \quad$ Intransigent Anti-Modernist}

In the last years of Pope Leo's papacy, a loosely affiliated, international scholarly movement labelled "Modernism" gained traction in the Roman Catholic Church. ${ }^{33}$ It sought to reconcile Catholic doctrines with advances in the historical, social, and exegetical sciences. Critical of the "intellectualism" of Scholastic theology and influenced by Kant's speculative agnosticism, those labelled "modernists" gravitated to modern, non-rationalistic philosophies such as the

30 Cited by Henri de Lubac, Theology in History, trans. Anne Englund Nash (San Francisco: Ignatius Press, 1996), 341n82. Billot's letter is undated. The first volume of Lebreton's Histoire du dogme de la Trinité (Paris: Beauchesne) was published in 1919. The second volume appeared in 1927.

$31 \quad$ See Jesus Villagrasa, "Origin, Nature and Initial Reception of the XXIV Thomistic Theses in the light of the controversy between Neo-Thomism and Suarezism," Doctor Angelicus: Internationales thomistisches Jahrbuch 6 (2006): 193-230, here 209-10.

32 Church historian Giacomo Martina, S.J., remarks that Billot and his protégé Guido Mattiussi, S.J., "spread accusations in the Vatican against Wernz," the superior general of the Society of Jesus. See $D H C J$, 2:1686.

33 See Daly, Transcendence and Immanence. 
"philosophy of action" of Maurice Blondel (1861-1949) and the "intuitionism" of Henri Bergson (1859-1941). Alarmed by developments in France, Rome targeted the writings of the biblical exegete Alfred Loisy (1857-1940) for censure. Billot played a crucial role in the 1903 condemnation of Loisy's writings. ${ }^{34}$ The merits of this condemnation notwithstanding, Billot was ill-prepared to appreciate the developments in biblical exegesis and the historical study of doctrines. He remarked that "dogmas have no history" 35 and that the study of the biblical literary forms was "vanity." ${ }^{36}$ For Billot, God is the author of Scripture; the human writers were merely stenographers. Doing theology is simply the logical deduction of what is contained in the deposit of faith, namely the revealed truths received and transmitted by the apostles both orally and in writing. Furthermore, Billot's maximalist view of magisterial authority ensured that the truths of faith have been handed on without distortion or adulteration. ${ }^{37}$ Billot maintained the immutability of revealed truths and rejected the notion that the dogmas of faith undergo historical development. ${ }^{38}$

On Sept. 8, 1907, Pope Pius X promulgated the anti-modernist encyclical Pascendi gregis, which memorably described modernism as "the synthesis

34 See La censure d'Alfred Loisy (1903): Les documents des congrégations de l'Index et du SaintOffice, ed. Claus Arnold and Giacomo Losito (Rome: Libreria Editrice Vaticana, 2009), 37-42 and passim. "Billot proves the errors of Loisy from his assured vantage point of neo-scholastic truth [...]. It is not surprising that several propositions formulated by Billot are found, more or less word for word, in the syllabus of the decree Lamentabili 1907" (38). Positions of Loisy singled out by Billot for censure were the "categorical refusal of the authority of the Gospel [and] the divinity of Jesus, and [refusal of] the divine institution of the Church [and] its dogmas and sacraments" (38).

35 Cited by Roger Aubert, Bilan de la théologie du xx siècle, ed. R. van der Gucht and H. Vorgrimler (Paris: Casterman, 1970), 431.

36 "Billot openly declares that he knows no other literary genres than Scripture itself" (Censure d'Alfred Loisy, 38). See Francois Laplanche, La Crise de l'origine: La science catholique des Évangiles et l'histoire au XX siècle (Paris: Albin Michel, 2006), 66-68. "In fact Billot's treatise on inspiration illustrates in an almost caricatured way the opposition between the biblicists (for whom the conception of inspiration entails the analysis [pratique] of texts) and dogmaticians like Billot who deduce the conception of inspiration and the scope of biblical inerrancy from a theological axiom: God is the author of Scripture" (68). Billot apparently was content that his students did not know that there was a biblical "problem."

37 Maurice Blondel, whose method of immanence was rejected by Billot, criticized both Loisy's reductive historicism and Scholastic "extrinsicism" that appealed to authority and disdains "subjectivity." In his critique of extrinsicism, Blondel does not explicitly name Billot. See Maurice Blondel, The Letter on Apologetics and History and Dogma. trans. and ed. Alexander Dru and Illtyd Trethowan (Grand Rapids: Eerdmans, 1994).

38 Billot expounded this intransigent position on the "immutability of tradition [which is] opposed to the modern heresy of evolutionism." De immutabilitate traditionis contra modernam haeresim evolutionismi (Rome: Typ. Institutis Pii IX, 1907). 
of all heresies." ${ }^{39}$ Billot's "fingerprints" are on this document and Lamentabili sane exitu, published the previous July, which condemned sixty-five propositions as modernist heresies. Many of these propositions were culled from Loisy's publications and echoed Billot's denunciations of Loisy's positions. ${ }^{40}$ Billot's intransigent anti-modernism earned him the confidence of Pope Pius x. In 1909, Billot was named an official consultor of the powerful Holy Office. In 1911, the pope made Billot a cardinal. ${ }^{41}$ Apparently his elevation to this dignity was against the wishes of Superior General Wernz and Billot himself. ${ }^{42}$

The initial phase of the anti-modernist campaign focused on biblical and doctrinal deviations. ${ }^{43}$ Among the measures officially enacted to root out suspected modernists and their sympathizers were the establishment of diocesan

39 Pascendi dominici gregis (on the doctrines of the Modernists) and Lamentabili sane exitu (syllabus condemning the errors of the Modernists), ASS 40:593-650.

40 Gabriel Daly makes a strong case for attributing primary authorship of the doctrinal section of the anti-modernist encyclical Pascendi gregis to Joseph Lemius, O.M.I. See Transcendence and Immanence, 232-34. See also Laplanche, Crise de l'origine, 41n1. Sesboüé reiterates an earlier view that Billot "was considered the principal redactor of the encyclical Pascendi (1907) which repeats, in fact, certain of his arguments" (Dictionnaire du monde religieux dans la France contemporaine, 62). For Billot's role in drawing up Lamentabili's syllabus of errors, see Émile Poulat, "Lamentabili," in Dictionnaire d'histoire et de géographie ecclésiastiques (Paris: Letouzey et Ané, 2008), 30:cols. 125-28, here 125. In any event, Billot played an important role in the preparation of these magisterial documents. For confirmation of Lemius as primary redactor of Pascendi gregis, see La redazione dell'enciclica Pascendi: Studi e documenti sull'antimodernismo di Papa Pio X, ed. Claus Arnold and Giovanni Vian (Stuttgart: Anton Hiersemann, 2020), 7-13.

41 Marc Agostino remarks: "Pius X held a vast consistory on November 27, 1911 to which he want[ed] to give a precise meaning. The consistorial allocution indicate[d] the antimodernist and conservative sense of this promotion where Billot and de Cabrières were put forward, whereas Della Chiesa, the archbishop of Bologna, was excluded." "De la signification de quelques consistoires au XXe siècle," in La Papauté contemporaine (XIX-XX siècles - Il Papato contemporaneo (secoli $X I X-X X$ ) (Città del Vaticano: Archivio Segreto Vaticano, 2009), 284.

42 Martina remarks that "Wernz received the cardinatial appointment of Louis Billot (November 30, 1911) as a disgrace for the Society." Wernz had to deal with a Society of Jesus "quite divided" with respect to its social and cultural apostolates. And although the Society had not defended the radical positions of Loisy, Tyrrell, and other modernists targeted by the anti-modernist condemnations, other questions, partly related to modernist concerns, left the Society "almost broken." These questions included the nature of obedience to the pope, the general attitude towards the modern world, the freedom of scholarly investigation, Thomistic or Suarezian philosophy, syndicalism and its orientation, how to deal with the modernists, etc. See $D H C J$, 2:1685-86.

43 Chenu "compared Billot's role in Roman theology to that of Cardinal Merry del Val [18651930] in Roman politics," recalling that "the person who directed this [anti-modernist] politics was Cardinal Merry del Val, the [Vatican] Secretary of State, the man trusted [de confiance] by Pius $\mathrm{x}$. A great intellect, but expressly reactionary. On another level, that of theology, it was a professor of the Gregorian, Fr. Billot, who acted" (Christophe Potworowski, 
vigilance committees and the prescribing of an anti-modernist oath (1910) for church officials. ${ }^{44}$ Billot was one of the principal drafters of the oath and argued that the refusal of the oath should be viewed as a "schismatic act." 45 However, the cardinals of the Holy Office preferred to view the taking of the oath as a "declaration of obedience," the refusal of which could disqualify a person from holding an ecclesiastical position. ${ }^{46}$

In the final years of Pius X's pontificate, the anti-modernist campaign of denunciation grew shriller and more fearsome. The alarm about "the diminution of truth among Catholics" shifted to the socio-political terrain. ${ }^{47}$ Unofficial watchdogs of orthodoxy, labelled "integralists," delated suspected modernists and their sympathizers, and intimidated Catholic scholarship and organizations working for social renewal. This integralist reaction reached a fever pitch in $1912-13 .{ }^{48}$ Certain works of the Society of Jesus and their leaders was targeted by the integralists. The French Jesuit social center Action Populaire [= AP] was subject to integralist attacks. AP applied Catholic social teaching to promote justice for the working class. AP was accused of "social" modernism for supporting the right of workers to unionize. ${ }^{49}$ Billot was one of its critics and his views were especially influential within the Roman curia. Jesuit Gustav Desbuquois (1869-1959), AP's director, engaged in correspondence with Billot in 1913, defending the natural law foundation and legitimacy of Christian labor unions. ${ }^{50}$ Though Billot did not retract his accusation against AP of "integral and revolutionary syndicalism," AP was able to narrowly escape condemnation

Contemplation and Incarnation: The Theology of Marie-Dominique Chenu [Montreal: McGillQueen's University Press, 2001], 42).

44 Pope Pius x prescribed "The Oath against Modernism" in his motu proprio Sacrorum antistitum (AAS, 2 [September 1, 1910]: 655-80), which was to be sworn by "all clergy, pastors, confessors, preachers, religious superiors, and professors in philosophical-theological seminaries" (656).

45 See Judith Schepers, "Tra fede e obbedienza: Osservazioni sullinterpretazione curiale del giuramento antimodernista," in La condanna del modernismo: Documenti, interpretazioni, conseguenze, ed. Claus Arnold and Giovanni Vian (Rome: Viella, 2010), 175-200, here 187.

46 Schepers, "Tra fede e obbedienza," 190.

47 See Émile Poulat, "La dernière bataille du pontificat de Pie X," Rivista di storia della Chiesa in Italia 25 (1971): 83-107.

48 This is amply documented in Émile Poulat, Intégrisme et catholicisme intégral: Un réseau secret international antimoderniste; La "Sapinière" (1909-1921) (Paris: Casterman, 1969). See especially 388-89; 392-97; 442-43.

49 See Paul Droulers, Politique sociale et christianisme: Le père Desbuquois et l'Action Populaire, 2 vols. (Paris: Édition Ouvrières, 1969-81). Regarding Billot's influence, see Droulers, 1:301-3.

$5^{\circ}$ This private correspondence has been edited by Paul Droulers; see "Le cardinal Billot, le Père Desbuquois et le syndicalisme ouvrier: Correspondance 1913-1914," Bulletin de littérature ecclésiastique 85 (1984): 196-209; 279-96; and 86 (1985): 35-45. 
by Rome. As we shall see, Billot's sympathies lay with the political and social program of Action Française. ${ }^{51}$

Finally, Billot's anti-modernism showed itself early in the pontificate of Pius XI. The pope privately queried curial officials including Cardinal Billot about the possibility of re-opening Vatican I. In his response, Billot maintained that "the age of Ecumenical Councils is now closed and terminated." He gave as "the most serious reason" for not convoking a council:

The one which would seem to me absolutely to militate for a negative reply. Resuming the Council is desired by the worst enemies of the Church, the modernists, who are already getting ready-as quite certain indications reveal-to profit from the estates general of the Church in order to make revolution, a new ' 89 , the object of their dreams and hopes. They will not succeed, of course, but we would see again those very sad days of the end of the pontificate of Leo XIII and of the beginning of that of Pius $\mathrm{x}$; we would see things even worse, and it would annihilate the happy fruits of the Encyclical Pascendi which silenced them all. ${ }^{52}$

Billot was especially fearful that "the proportion, considerable both in numbers and in means of action, of the Irish-American element in Council, would introduce procedures of discussion and propaganda more in accord with democratic usage than with ecclesiastical traditions." ${ }^{n 3}$

$5^{1}$ "[W]hat seduces Cardinal Billot is the principle of authority in Action Française, and I believe what repulses him in Action Populaire is that he thinks he sees a war on authority, [its] overthrow, 'democratism' as he says" (Desbuquois to Fine, the Jesuit assistant for France) cited in Droulers, "Le cardinal Billot," 1:359.

$5^{2}$ Joseph Komonchak, "Popes Pius XI and Pius XII and the Idea of an Ecumenical Council," at https://jakomonchak.files.wordpress.com/2012/o1/pius-xi-pius-xii-on-a-council.pdf (accessed April 5, 2021, 2021). Komonchak cites Giovanni Caprile, "Pio XI, la curia romana e il concilio," La Civiltà cattolica 120/2 (1969): 121-33, 563-75 (included as an appendix in Caprile's Il Concilio Vaticano II [Rome: Ed. "La Civiltà cattolica," 1969], 5:681-701), cited from the latter, 692. I am indebted to Jon Kirwan for this reference; see An Avant-garde Theological Generation: The Nouvelle Théologie and the French Crisis of Modernity (Oxford: Oxford University Press, 2018), $107 n 46$.

53 Caprile, Il Concilio Vaticano II, 5:688. Billot's was one of the entirely negative responses to Pius XI's query from the twenty-nine responding curial cardinals. In a global survey of more than one thousand ecclesial leaders, only thirty-four clearly opposed convoking a council. See Komonchak, "Popes Pius XI and Pius XII," 3-5. 
Throughout the nineteenth and twentieth centuries, French Catholics had been divided in their response to the French Revolution and its legacy. A minority position, labelled "liberal" Catholicism, was prophetically championed by Félicité Robert de Lamennais's (1782-1854) and Charles Forbes René de Montalembert (1810-70). They sought a qualified reconciliation between the church and modernity. During the pontificates of Gregory XVI (r.1831-46) and Pius IX (r.1846-78), this position was firmly rejected by Rome. However, Pope Leo XIII (r.1878-1903) initiated a new policy of engagement in the social and political realms. His encyclical Rerum novarum (1891) was a catalyst for "social" Catholic movements that supported the working class in its struggles for justice. ${ }^{54}$ In 1892 , Leo promulgated Au milieu des solicitudes that was a plea for French Catholics to honor the institutions that the French people had chosen for themselves. This call for a "ralliement" to the Third Republic did not succeed in uniting French Catholics. A few years later, in the wake of the infamous Dreyfus Affair, the anti-democratic, counter-revolutionary, monarchist politico-cultural movement Action Française attracted significant support among French Catholics. ${ }^{55}$ Charles Maurras (1868-1952), a cradle Catholic who had lost his faith as a teenager, was AF's maittre à penser. In response to the aggressive laicité of the French Third Republic (1870-1940) whose anticlerical legislation culminated in the Law of Separation (1905) that revoked the legally privileged status of the Roman Catholic Church in France, AF presented itself as the defender of the church's interests. In accord with the "thesis" that favored the "confessional" state, AF called for the legal re-establishment of the Roman Catholic Church as the nation's official religion. Maurras heaped unstinting praise on the Roman Church as a bulwark against barbaric disorder. He declared that only the restoration of the alliance between church and state could defeat the enemies of France. Maurras's political program offered a concrete and practical outlet for those who despaired of reversing the inimical, anti-clerical policies of the Third Republic by constitutional means. "Order,

54 See Peter Bernardi, "Social Modernism: The Case of the Semaines Sociales," in Catholicism Contending with Modernity: Roman Catholic Modernism and Anti-Modernism in Historical Context, ed. Darrell Jodock (Cambridge: Cambridge University Press, 2000), 277-307.

The classic study of AF is Eugen Weber's Action Française: Royalism and Reaction in Twentieth Century France (Stanford, CA: Stanford University Press, 1962). For the magisterial treatment of the history of Action Française and the Catholic Church, see Jacques Prévotat, Les catholiques et l'Action française: Histoire d'une condamnation 1899-1939 (Paris: Fayard, 2001). See also Michael Sutton, Nationalism, Positivism and Catholicism: The Politics of Charles Maurras and French Catholics, 1890-1914 (Cambridge: Cambridge University Press, 1982). 
discipline, and hierarchy" were AF's watchwords. Its socio-political program was designed to reinstill these traditional values and counter the root malady afflicting French society: the destructive "individualism" unleashed by the Protestant Reformation and the French Revolution. The diagnosis pointed to the remedy. As "the apostle of tradition," Maurras would save France from pernicious "liberalism" and democratic parliamentarianism by returning to the traditional institutions that were the foundations of its past greatness. The restoration of altar and throne, with a program of decentralization, was the antidote to France's predicament. Not surprisingly, Maurras's anti-liberal and counter-revolutionary views resonated with the Roman Catholic Church's dominant restorationist, anti-liberal, intransigently anti-modernist mentality.

However, a Catholic alliance with Maurras and AF also received severe criticism, not least because of the blatant paganism of Maurras's writings. What Maurras really appreciated about the Roman Catholic Church was its commitment to "order, discipline, and authority," not the values of Christ. Maurras had only contempt for "the venom of the Magnificat" and the "frenzy of the Jewish prophets." ${ }^{56}$ Catholic critics also deplored AF's slogan politique d'abord (politics first) that served to instrumentalize the church on behalf of AF's political and cultural agenda. These critics proved to be prescient. ${ }^{57}$

Action Française found support at the highest ecclesiastical levels including Billot who extolled Maurras and AF as the best defense in France against liberalism and democracy. ${ }^{58}$ During the Modernist period, as we saw above, Billot represented a certain type of Thomism that often became a sort of weapon [instrument de guerre] in the hands of ecclesiastical orthodoxy police. Maurras won favor by championing Aristotle and "Thomism." ${ }^{59}$ Maurras made

56 See Charles Maurras, Le Chemin de Paradis (Paris: Flammarion, 1928; reprint).

57 See Peter J. Bernardi, Maurice Blondel, Social Catholicism and Action Française: The Clash over the Church's Role in Society during the Modernist Era (Washington, DC: Catholic University Press of America, 2009).

58 Prévotat remarks: "Father Billot became a great admirer of AF. His concerns were essentially theological. Neither his nature nor his character drew him to political action. Thus he is not found in the first line of AF's battles" (Catholiques et l'Action française, 74). Billot was not unique among French Jesuits who were AF sympathizers. See Peter J. Bernardi, "French Jesuits and Action Française," in "The Tragic Couple": Encounters between Jews and Jesuits, ed. James Bernauer and Robert A. Maryks (Leiden: Brill, 2014), 183-202. See also Étienne Fouilloux, Les jésuites à Lyon XVIe-XXe siècle, sous la direction d'Étienne Fouilloux et Bernard Hours (Lyon: Ens Éditions, 2005), 263.

59 Philippe Chenaux remarks that it was "a certain reading of St. Thomas, strongly tinged by Aristotelianism, which insisted on the autonomy of reason and the perfection of the natural order, that permitted the collaboration of Catholics with Action Française" (Chenaux, Entre Maurras et Maritain [Paris: Cerf, 1999], 14). See also Prévotat, Les catholiques et l'Action 
use of Billot's authority when the cardinal presented a specially bound copy of Charles Maurras's L'Action française et la religion catholique to Pope Pius X in 1913 to stave off a rumored condemnation of Maurras's writings. The pope is said to have called Maurras "a good defender of the Holy See and of the Church." ${ }^{60}$ Pius x refused to promulgate a decree drawn up by the Holy Office of the Index that condemned some of Maurras's more flagrant anti-Christian (and anti-Jewish) writings. ${ }^{61}$ Maurras and his movement seemed to have cast a spell over important sectors of the church hierarchy and the French Catholic laity. Billot played a significant role in protecting Maurras from public ecclesiastical sanction. ${ }^{62}$

In the 1910 edition of his De ecclesia, Billot favorably cited Maurras's Libéralisme et liberté. ${ }^{63}$ Billot made a sustained attack on liberalism's claim that liberty is the first, most basic human good, whose exercise eschews all external coercion or restriction. ${ }^{64}$ Billot denounced this principle, considered

française, 218-26; and Etienne Gilson, The Philosopher and Theology, trans. Cécile Gilson (New York: Random House, 1962), 58-61. Perhaps the most prominent Thomist to support AF was Jacques Maritain, considered the "official philosopher" of AF for a few years after the First World War. See Bernard E. Doering, Jacques Maritain and the French Catholic Intellectuals (Notre Dame: Notre Dame Press, 1983), 6-36. See also Michael J. Kerlin, "AntiModernism and the Elective Affinity between Politics and Philosophy," in Catholicism Contending with Modernity: Roman Catholic Modernism and Anti-Modernism in Historical Context, ed. Darrell Jodock (Cambridge: Cambridge University Press, 2000), 115-41. French Jesuits Pedro Descoqs, a Suarezian Scholastic philosopher, and Pierre Rousselot, a more historically based Thomist, were also AF sympathizers.

6o Cited by Adrien Dansette in "Correspondence," Études 279 (December 1953): 391-92. Pius x's Cardinal Secretary of State Merry del Val is reported to have remarked: "We prefer an unbeliever like Maurras who defends the rights of the Church, to a heretic like Monsieur Piou" (cited in Prévotat, Les catholiques et l'Action française, 175n6). Jacques Piou was a French Catholic politician who co-founded the democracy-oriented political party Action Libérale Populaire.

61 On January 15, 1914, the consultors of the Index agreed to condemn five works of Maurras but were unable to achieve accord on two others. On January 26 , the cardinals added the journal l'Action française (but not the AF daily newspaper). On the 29th, Pope Pius X ratified the decree, but indefinitely deferred its publication. "Damnabilis, non damnandus," the pope remarked. See Poulat, Intégrisme et catholicisme intégral, 402; and Prévotat, Catholiques et l'Action française, 192-94, here 194.

62 See Prévotat, Les catholiques et l'Action française, 175-94, which gives a detailed account of the efforts to protect Maurras's works from public condemnation. Maurras was protected "by a cooperation of a Roman group of French integralists: Joseph Lemius, Pie de Langogne OFMCap [...] Louis Billot, S.J." (La redazione dell'enciclica Pascendi, 13).

63 See Ludovico Billot, S.J., Tractatus De ecclesia Christi (Prati: Libraria Giachetti, 1910), 2:36n1-37n1.

64 Billot, Tractatus De ecclesia Christi, 17-59. This section treats "de errore liberalismi et variis eius formis." A French translation of this section entitled: "les principes de 89 and leurs 
sacrosanct by the "principles of 1789 ," as false and chimerical, and especially disastrous for the practical consequences it entailed.

The essential irreligiousness or impiousness of the principle of Liberalism will be readily seen by anyone who duly weighs the fact that it was the cardinal principle of the French Revolution, of which has been said with truth that its satanic character was so explicit, so visible, that it is distinguished thereby from every other thing that had ever occurred throughout the whole previous course of history [...]. For Liberalism, for all that it is worth, intends the emancipation of the individual, for whom it desires to preserve absolutely intact that supreme and principal good of man which is Liberty. Moreover, it maintains that society is repugnant to the emancipation of the individual — society, that is organized society, society formed on the basis of stable ties and laws - society, in fine, really deserving of the name society. [...] It is manifest, therefore, that it is the task of liberalism to dissolve all social organs into one. For, as the organs of the physical body are not molecules, or atoms, or cells, but rather limbs and members, so also the organs of the social body are not individuals, but the family, the guild, and the municipality. And if these be once supposed to be de-articulated or disorganized within the organism, to which they belong, it necessarily follows that all real liberties must perish utterly $[\ldots]$. Nothing can now remain except the gigantic and colossal State, an omnivorous thing, which, having destroyed all inferior organization and autonomy, will absorb in itself all force, all power, all right and all authority, and become the sole administrator, procurator, instructor, preceptor, educator and guardian, until it becomes also the sole proprietor, owner and possessor. ${ }^{65}$

The early editions of De ecclesia, in addition to frequent references to counterrevolutionary thinkers such as Joseph de Maistre (1753-1821), contained two lengthy citations from Maurras that diagnose "Liberalism," their shared bête noire:

In the political order, Liberalism declares in the very first clause of [Rousseau's] Social Contract, and in the first article of the Declaration of the

conséquences" was published in 1989 under the name of "Cardinal Louis Billot" (trans. Yves Rousselot [Paris: Tequi]. Billot gave his approval to an English translation: "Liberalism: A Criticism of Its Basic Principles and Divers Forms," trans. George Barry O'Toole (Beatty, PA: Archabbey Press, 1922). This translation will be cited.

65 O'Toole, trans., "Liberalism," 47, 39-40, and 44. 
Rights of Man, that man is born free. Liberalism would detach the individual human being from his antecedents, whether natural or historical. It would liberate him from family-ties, corporative ties and all other ties, whether social or traditional. Only because it is necessary to live in society and because society needs a government, will Liberalism establish a government for society upon the basis of one vote or suffrage to each individual liberty, and of the taking into account of these sovereign votes. The majority, expressing what Rousseau calls the general will, for that reason also, after a fashion, express the general liberty. The will of the majority becomes thenceforth a decree of law against which no one at all will have recourse in regard to anything, however useful and reasonable, or no matter how precious and sacred that person or things may be. Liberty at the very outset establishes a rule which methodically ignores all individual forces and particular liberties. Its vaunt is that it created uniquely and exclusively the liberty of each single individual; but in practice, history shows clearly that this individualism weakens the individuals. This is the first effect. Its second effect is to domineer, without any recourse of right, over all individuals not belonging to the party of the majority party, and thus to destroy the last refuge of real liberties. ${ }^{66}$

In an era when the church stressed hierarchy and traditional authority in society, Maurras's analysis of the ills of modern society were viewed favorably by more than a few highly placed ecclesiastics. Billot, however, was not an uncritical admirer. In a 1915 letter to Maurras, Billot did not mince his words in severely criticizing Maurras's book L'Etang de Berre which Mauras had personally addressed to him:

The book is bad, very bad, and it recalls the worst pages of Anthinéa. From beginning to end it is the old paganism in its most ugly nudity. It is the most desolate materialism. It is the negation of God, of the soul, of our immortal destinies, and by that itself, of everything that can lift up the unhappy human creature to any sort of ideal. It is with "the abyss"

66 Billot, "Liberalism," 45-47. The translation has been slightly amended. For the original, see Billot, Tractatus de ecclesia Christi, 2 vols. (Prati: Libreria Giachetti, 1910), 2:36n1-37n1, citing from Maurras's Libéralisme et liberté (Paris: Aux bureaux de l'Action française, 1906), $5 \mathrm{ff}$. This citation and a second citation in which Maurras criticized "the government of the majority [du nombre] [that] tends to disorganize the nation. It necessarily destroys all that which moderates or tempers it, all that differs from itself: religion, family, traditions, classes, organizations of every type, etc." (9 ff.) were excised from the third edition of Billot's De ecclesia Christi (Rome: PUG, 1929). 
which is "the only god," the doctrine of nothingness and of despair. Consequently, it is absolute nihilism, no matter the dazzle of flowers under which this philosophy of death seeks to conceal itself.67

Billot's candid criticism was undoubtedly intended to make Maurras think again about the Catholic faith he had abandoned as a teenager. Nevertheless, though Billot discreetly criticized Maurras's personal beliefs in private, he remained a public supporter. ${ }^{68}$ In 1922, Billot openly declared that "against liberalism and democracy, there was nothing better than Maurras." 69

\section{Louis Billot's Resignation}

Action Française reached its apogee of influence following the First World War. In the post-war period, authoritarian, nationalist movements like AF gained favor in the context of growing political, economic, and social malaise, compounded by the fear of Bolshevism. But the dark side of AF was largely ignored: "Between the two [world] wars, AF was the principal foyer and the 'spearhead' of French anti-Semitism."70 But AF's spell over many French Catholics was about to be broken. Alarmed by the influence of Maurras and AF on Catholic youth, the conservative French Cardinal Pierre-Paulin Andrieu (1849-1935), at Pope Pius XI's urging, issued a pastoral letter in August 1926, that denounced the "atheism, agnosticism, anti-Christianity, anti-Catholicism, [and] amoralism of the individual and society" taught by the AF directors. ${ }^{71}$ Then, in December 1926, Pope Pius XI peremptorily moved to terminate the

67 "Lettre du Cardinal Billot à Charles Maurras (Rome, Octobre 28, 1915)," in Études maurrassiennes (Aix-en-Provence: Centre Charles Maurras, 1986): 5/2:583-85, at 583 . See also Prévotat, Catholiques et l'Action française, 208.

68 In private correspondence, Billot continued to criticize the rank paganism found in Maurras's writings. For example, in 1926, Billot wrote to a cleric named Paul Halfants (18731945), who was quite indignant that some of Maurras's books had been condemned by the Holy Office of the Index. Billot wrote that "the blasphemies of Maurras [...] surpass [...] all that the entire collection of ancient literature can offer. It is Satan in person who speaks by his [Maurras's] mouth." See Bulletin religieux du diocèse de la Rochelle et Saintes 47, vol. 68 (May 21, 1932): 378-80.

69 Cited in Jules Pierrard, Juifs et catholiques français (Paris: Cerf, 1997), 236.

70 Pierrard, Juifs et catholiques français, 235-37. Pierrard remarks that Vichy's anti-Jewish legislation is contained in germ in Maurras's opinions that appeared in the newspaper L'Action française (November 27, 1920).

71 AAS 18 (August 25, 1926): 382-85. 
Catholic alliance with $\mathrm{AF}^{72}$ Making public the condemnation of Maurras's anti-Christian writings that had been deferred by Pope Pius X, Pius XI forbade Catholic participation in the movement and prohibited the reading of the AF journal. This provoked great consternation among French Catholics who were convinced that their participation in AF was simply the exercise of their just liberty in an area that did not concern the proper sphere of spiritual authority. The pope maintained that the whole matter did engage his properly spiritual authority. ${ }^{73}$ The response of the AF leadership and some of its Catholic sympathizers was anything but acquiescent. Though they had always claimed to be pro-Rome, they resisted Rome's intervention. Rome then enforced stringent measures to compel compliance by French Catholics. Not the least of its disciplinary measures was the forced resignation of Billot.

On December 19, 1927, meeting with a group of cardinals gathered in "secret consistory," Pope Pius XI announced "that the most eminent Louis Billot had renounced the sacred Purple" and had returned to the "simple life" of a Jesuit priest. ${ }^{74}$ Jesuit Superior General Włodzimierz Ledóchowski (1866-1942; in office 1915-42) had been notified three months earlier and had already escorted Billot, reduced to the status of a simple priest, to permanent retirement at the Jesuit novitiate at Galloro, outside of Rome. The official version held that

with the permission of the Holy Father he has set aside his cardinatial dignity and to the edification of all has gone to Galloro, the [Jesuit] novitiate of the province of Rome where Father General accompanied him. For a longtime the Cardinal has dreamed of taking this step, saying that he wanted to prepare himself for death. Some weeks ago he decided to

$72 \quad A A S 18$ (December 20, 1926): 517-24. The condemnation of AF had the effect of liberating a generation from the "clerical first fruits of Aeterni Patris, a Thomism that allied itself with social anti-modernism. From 1927, the younger generation of French Catholic Thomists ceased to call themselves believers in 'reason' and announced their faith in 'Christian Humanism.' With the papal condemnation of Action Francaise, a new kind of Thomism began to blossom; for a second time, a 'pontifical intervention' would 'create a Thomist Renaissance' in the writings of Gilson, Maritain, and Chenu" (Francesca Aran Murphy, Art and Intellect in the Philosophy of Etienne Gilson [Colombia: University of Missouri Press, 2004], 101). Murphy refers to Chenu's article "Les sens et les leçons d'une crise religieuse," Vie intellectuelle 13 (1931): $35^{6-80}$, here 370 , $376^{-} 77$, and 380 .

73 Jacques Maritain, who had been an AF supporter, rallied to support the papal condemnation with his book Primauté du spiritual (Paris: Plon, 1927); English translation: The Things That Are Not Caesar's, trans. J. F. Scanlan (New York: Charles Scribner's Sons, 1930).

74 See AAS 19 (December 22, 1927): 438-39. 
ask the permission of the Holy Father. The Pope after mature reflection and seeing the Cardinal's ardent desire, granted him the authorization. ${ }^{75}$

But this account did not give the full story of the Billot's resignation of his "cardinatial dignity." It was known that in the fall of 1926, Billot had sent a private note [carte devisite] to the prominent AF politician and journalist Léon Daudet (1867-1942), expressing strong support for Daudet and other AF leaders who rebuffed Cardinal Andrieu's pastoral letter. ${ }^{76}$ Without Billot's permission, his note was circulated in the French press. This greatly irritated the pope. There was a report of a difficult meeting between Billot and the pope. ${ }^{77}$ This was followed by a meeting between Billot and Pietro Gasparri (1852-1934), the cardinal secretary of state, on November 6. On December 2, Gasparri revisited his curial colleague, and apparently in an informal way and perhaps in an "excited moment," proposed to Billot (evidently in the name of the pope) two solutions to the problem: either to publish a rectification of his note to Daudet with a repudiation of his support for $\mathrm{AF}$, or else submit his resignation to the pope. The following day Billot wrote a firm letter to Gasparri:

I have not yet recovered from the great surprise prompted by your visit. A Cardinal of the Curia who openly puts himself in opposition to the pope. Let's see $[. .$.$] , is that the reality of the situation? I say no, no, no. In fact,$ the response in question of the incriminated note [...] was not a response made to the pope, but what is altogether different, to Cardinal Andrieu. ${ }^{78}$

Billot bitterly concluded: "For me, I could easily disinterest myself in the fate of AF. But what I cannot be consoled about, what brings tears to my eyes, is the immense disesteem that has befallen the Holy See everywhere in France, Catholic and non-Catholic."79 Two days later, Billot wrote Gasparri that he did not intend to publish a retraction, thus opening the door to the other option,

75 Archives of the Province of France of the Society of Jesus [hereafter AFsI], Fonds Billot 1846-1931, folder H Bi; dated September 20, 1927; and initialed F[elix] M[ollat] (the Jesuit provincial superior of the Paris province).

76 See Sergio Pagano, "Dalla porpora al chiostro: L'inflessibilità di Pio XI verso il cardinale Louis Billot," in La Papauté contemporaine (XIX-XX siècles) - Il papato contemporaneo (secoli XIX$X X)$ (Città del Vaticano: Archivio segreto vaticano, 2009), 398.

77 "A stormy conversation after which he had been on the verge of submitting his cardinal's cap" [French original: "une conversation orageux après laquelle il a été sur le point de lui remettre sa calotte cardinalice" (Roman Archives of the Society of Jesus [hereafter ARSI], folder: "ad Franciae '27, AF: B").

78 Pagano, "Dalla porpora al chiostro," 399.

79 Pagano, "Dalla porpora al chiostro," 399. 
resignation from the Sacred College. On December 5, 1926, the Osservatore romano, without a retraction from Billot, sought to smooth things over by indicating the private nature of Billot's communication to Daudet, "made public by a blameworthy indiscretion," and claiming that the cardinal had expressed to the Holy Father his displeasure, "intending that the note ought to be considered as not written." ${ }^{80}$ Reacting sharply to the Osservatore romano article, Billot wrote Gasparri in defense of AF by citing the pope's published remarks that Catholics are entirely free in the matter of choice of political regime. For the next eight months, while the Vatican issued harsh disciplinary measures to compel French Catholics to cut ties with AF, Billot's situation was quiescent. Then in early August, 1927, a visiting French bishop from Algeria reported to the pope a conversation he had had with Billot in which Billot, reluctant at first, expressed his unrepentant support for AF. On learning this, Pius XI is said to have had a fit [andasse 'in furia']. That very day he summoned Ledóchowski and directed him personally to express to Billot the pope's vexation over his failure to comply with papal policy. The next day, after delivering the pope's message, Billot told Ledóchowski that he had not changed his ideas and that in a non-religious question if the pope took offense that a cardinal had a different perspective from his own, he was disposed to offer his resignation. The Jesuit superior general was very upset and reported to Gasparri the results of his meeting with Billot. Billot then wrote to the pope:

Very Holy Father, after two conversations I had yesterday with Fr. Ledóchowski, of which Your Holiness knows the occasion and subject, after having also consulted God in prayer and observed what our Father St. Ignatius recommended to us to do before any recourse to superiors: I believe I must carry out the project which for some time I have reflected on [which] is to depose in the hands of your Holiness my renunciation, pure and simple, the Cardinatial dignity and all of its privileges. ${ }^{81}$

Billot did not sign the letter with his formal title nor did he make any explicit reference to the disagreements over $\mathrm{AF}$ as a reason for his desire to resign. On August 12, Gasparri's response to Billot, corrected by the pope's own hand, granted Billot's wish to retire to a house of the Jesuit order and, as a humble religious, to prepare for death. The pope cited the edifying example of Cardinal Odeschlachi's retirement. ${ }^{82}$ On August 9th, Ledochówski wrote to Gasparri

80 Pagano, "Dalla porpora al chiostro," 400.

81 Pagano, "Dalla porpora al chiostro," 402-3.

82 In 1838, Pope Gregory XVI gave Cardinal Carlo Odeschalchi (1785-1841) permission to resign to enter the Jesuit order. 
that Billot "read the letter of your eminence with great satisfaction and showed himself very glad at the permission to resign his cardinal's dignity."83 $\mathrm{He}$ also remarked that it seemed that Billot wanted to return to France, but consented to go to Galloro. He needed to put his things in order and would be ready to move in mid-September. There was to be absolute secrecy about the move. On September 13, Pope Pius conceded a brief private audience with Billot and then presented him with the gift of an artistic crucifix "which gift was to console the cardinal in the last steps of his Calvary which his own indomitable toughness of character had procured for him." ${ }^{84}$ The Jesuit saluted the pontiff with the customary genuflection and the pope accompanied this gesture with his apostolic benediction. On the evening of the following day, accompanied by Ledochówski, the ex-cardinal left Rome with only two small valises. The General asked the pope to pray for "the poor Father who evidently, as I was able again to confirm during these days, has certain fixed ideas, from which he is not able to free himself." ${ }^{\prime 5}$ When Ledochówski reported Billot's resignation to his staff, he referred to the difficulties concerning AF. The prevailing view at the time was that Billot's resignation was prompted by the cardinal's discomfort with curial tensions and by a genuine spirit of humility, but that it had its origin in his closeness to AF and was therefore in some way on account of his difference of view with the pope. ${ }^{86}$ The Vatican account was silent about the disagreements concerning AF, but after the pope announced the resignation to the Sacred College of Cardinals in December, 1927, he had an archival document drafted that he himself revised. This authoritative final resume of the event notes the "grave circumstances" that prompted the resignation, including the great scandal given to French Catholics by the ex-cardinal's support for $\mathrm{AF}^{87}$

83 Pagano, "Dalla porpora al chiostro," 404-5.

84 Pagano, "Dalla porpora al chiostro," 405.

85 Pagano, "Dalla porpora al chiostro," 405.

86 Cardinal Alfred Baudrillart noted in his diary: "It is the pope who has taken the initiative in the renouncement of Cardinal Billot from the cardinalate" (Pagano, "Dalla porpora al chiostro," 395).

87 Pius XI ordered Mons. Borgongini Duca to draft an archival note intended to serve as a memoria of Billot's resignation: "The Holy Father, after repeated admonitions, which the Cardinal confessed to having failed ['the passion is stronger than me'], had ordered said by the intermediary of Fr. General [Ledóchowski] that things could not continue and that he had wanted guarantees. It was then that his Eminence spoke of the intention he had to renounce the Cardinatial dignity, as the said Fr. General explained in a letter of August 9: 'I have communicated in a very gentle way to His eminence Cardinal Billot that which the Holy Father enjoined me to say to him and at the same time to confirm His Eminence in the intention that he had first manifested to me spontaneously, that is to ask the Holy Father 
By all accounts, Billot peacefully came to terms with this humiliation. He kept a low profile in retirement, re-editing some of his manuals. He is said to have maintained his "fixed ideas," but was respectful of the pope in his personal communications. ${ }^{88}$ In 1928, he composed a letter, published in France and Italy, in which he expressed his complete conformity to the orders of the pope and his disapproval of any spirit of rebellion.

If I may voice my sentiments as a simple religious who has always had a most ardent love for the Holy Church and for his country, it is to say that all, even at the cost of very painful sacrifices, should end by submitting themselves to the common Father of the faithful. Otherwise, they can enter only on the most dangerous of roads and thus gravely compromise their eternal salvation. This wish, or rather this prayer, is that of a man who, already in his eighty-third year, is preparing himself to appear in the near future before the tribunal of God and who does not wish to answer to his Judge for the souls of his brothers. ${ }^{89}$

In the wake of Billot's death in 1931, Pagano remarks that "the polemical climate between the Holy See and AF was far from settling down." 90 The international press, with a few exceptions, saw in the figure of the deceased Jesuit a "victim" of the Roman curial system and viewed his resignation to be a "disgrace." ${ }^{11}$ In response to frequent articles that invoked Billot's "patronage" to justify AF's dissent from Rome's directives, the French Jesuit journal Études reprinted Billot's 1928 letter. ${ }^{92}$ We now know that "the true story is more complex, touching two

permission to depose the Cardinatial dignity and to retire to a house of the Company to prepare for death. This archival note has been written by order of the Holy Father who has approved its contents" (F. Borgongini Duca in Pagano, "Dalla porpora al chiostro," 409).

Prévotat remarks: "After his retirement, the cardinal remained faithful to AF and to his intransigent friendships, but he acted so that his attitude was not exploited by AF" (Catholiques et l'Action française, 486).

89 Billot's letter, dated March 2, 1928 (Galloro), was addressed to Jesuit Henri du Passage, editor of the French Jesuit periodical Études. It was published in the French periodical La Croix (March 6th) and again (in Italian) in Civiltà cattolica (March 17). An English translation, from which the cited passage is taken, was published in Woodstock Letters 57 (1928): 266-67, here 67.

90 Pagano, "Dalla porpora al chiostro," 409.

91 The death notice in the Osservatore romano continued to accredit the version that Billot had made repeated requests to resign.

92 "Réponse à une calomnie," Études 210 (1932): 491-92. 
highly significant figures, papa Ratti and Billot."93 Ironically, it was Billot who had crowned the newly elected Pope Pius XI in 1922.

\section{$7 \quad$ Billot and the Integralist Mentality}

Both Chenu and his fellow Dominican Yves Congar (1904-95) characterized Billot's mentality as "integralist." 94 Congar elaborated an eight-point description of this mentality. ${ }^{95}$ First, integralism [intégrisme] tends to be pessimistic, stressing the pernicious consequences of original sin and evil in the world; second, integralism favors hierarchical authority to maintain order and to suppress error; third, it is mistrustful of the notion of development and of appeals to "life" and "experience" that suggest change and relativism; fourth, integralism is legalistic, maximizing the demands of what it means to be Catholic; fifth, it stresses the objective, intellectual component of faith, showing scant interest in the personal appropriation of faith and the ways in which it develops; sixth, integralism places great value on deductive reason and demonstrated conclusions, eschewing inductive thinking or appeals to experience, to personal witness, or to the internal workings of conscience. "It is deeply attached to the kind of neo-scholasticism that developed at the end of the nineteenth century $[\ldots]$. Their world is completely defined." ${ }^{\prime 6}$ Seventh, with respect to the church, it accentuates the strict, authoritarian side of things. It maximizes the authority of statements coming from Rome, considering hierarchical directives as definitive. In general, integralists cannot imagine the truth as a fullness that arises out of a communion of believers who are all filled with spiritual gifts. They see only conclusions, not problems. Finally, a certain ecclesiology corresponds to these attitudes. Although they understand the church as a mystery

93 Pagano, "Dalla porpora al chiostro," 409-10.

94 Congar remarked: "The integralism of the historic era of modernism, that of men like Cardinal Billot [and] Cardinal Merry del Val was the case of men completely involved in the attitudes of the [political] right" (Appendice III : Mentalité 'de droite' et Intégrisme en France, in Vrai et fausse réforme dans l'Église [Paris: Cerf, 1950], 611).

95 Paul Philibert, "Congar's Ecclesiastical Subtext: Intransigent Conservatism," in Yves Congar, My Journal of the Council, trans. M. J. Ronayne, O.P. and M. C. Boulding, O.P. (Collegeville, MI: Liturgical Press), l-li. I have paraphrased Philibert's summary of what Congar wrote in the third appendix of the original edition of Vrai et fausse réforme. This appendix was omitted from the revised edition (1968). Concerning the removal of this appendix, Congar wrote that this constituted neither "a change of heart nor a retraction" (Vrai et fausse réforme dans l'Église, 2nd ed. [Paris: Cerf, 1968], 7).

96 Philibert, "Congar's Ecclesiastical Subtext," li. 
of grace and they clearly affirm the mystical dimension of the church, the church itself is considered only according to the structure of authority, something exterior to the religious subject, and in such a fashion that everything is imagined as coming from on high. From one end of the spectrum to the other, integralism emphasizes what was, what is given, what is commanded. (emphasis in original). To Congar's description of integralism, Jesuit Henri de Lubac (1896-1991) added that it is "a mixing of matters of the faith with a sociopolitical complex." ${ }^{\prime 97}$ These characteristics of integralism identified by Congar and de Lubac help understand a recurrent tendency in modern church life that is by no means vanquished. ${ }^{98}$ It is not difficult to correlate several of them with Louis Billot's mentality. Billot's speculative theology was mistrustful of the notion of development and of appeals to "life" and "experience" that suggest change and relativism. He stressed "the objective, intellectual component of faith, showing scant interest in the personal appropriation of faith and the ways in which it develops." And he placed "great value on deductive reason and demonstrated conclusions, eschewing inductive thinking or appeals to experience, to personal witness, or to the internal workings of conscience." Billot's support for the anti-democratic, authoritarian ideology of Action Française is an example of theological ideology in which a problematic political option is attached to an historically conditioned understanding of the church. This theologico-political stance characterized some of the participants at Vatican II who had been influenced by Billot's mentality.

97 Henri de Lubac, Carnets du Concile, 2 vols. (Paris: Cerf, 2007): "I think I know well what is the integralism of our century: its origins, its history, its mentality, its presuppositions, its procedures, etc. Some of its characteristics: a (late) scholastic systematization taken for the absolute, obstructing the living sources of doctrine; a 'fundamentalism' contrary to the life of the spirit, just as to the spirit of the Gospel; a mixing of matters of the faith with a sociopolitical complex; a mentality of systematic and ill-natured suspicion, engendering an effort to discredit anyone who manifests independence; a tendency, sometimes pushing very far, to organize into a clan; procedures of intrigue, in the service of a desire for domination. And I have observed (in history or directly) how, by that, integralism sometimes succeeds in intimidating the authorities of the Church" (423).

98 See Joseph Ratzinger, Principles of Catholic Theology: Building Stones for a Fundamental Theology, trans. Sister Mary Frances McCarthy, S.N.D. (San Francisco, CA: Ignatius Press, 1987). "We are witnesses today of a new integralism that may seem to support what is strictly Catholic but in reality corrupts it to the core" $(376-77)$. 
Billot's theological writings and anti-modernist mentality continued to have an influence up to the Second Vatican Council (1962-65) and beyond. ${ }^{99}$ When on January 25, 1959, Pope John XXIII (r.1958-63) announced before a stunned group of curial cardinals his intention to convene an ecumenical council, Billot's negative assessment about convoking a council was recalled. ${ }^{100}$ Intransigent anti-modernism perdured among some ecclesiastics who participated at Vatican II. ${ }^{101}$ The "Roman" school of neo-Scholasticism that Billot's theological positions typified influenced the preparatory schemata and the mentality of some bishops, labelled the "minority," at the council, some of whom had been his students. ${ }^{102}$ These positions have been termed "nonhistorical" orthodoxy. ${ }^{103}$

The influence of this Roman theology was especially evident in the De ecclesia preparatory schema that was strongly criticized at the council's opening session by Bishop Emiel-Jozef de Smedt (1909-95) from Bruges, Belgium for its triumphalism, clericalism, and juridicism. ${ }^{104}$ This schema was marked by an anti-Protestant polemical edge and emphasized hierarchical authority, especially the pope, and the identity of the Roman Catholic Church as the only true church. ${ }^{105}$ As noted by de Lubac, the schema reflected Billot's strongly

For example, Billot's works were often referenced in the widely used Spanish Jesuit manual series published in the 1950s by the Biblioteca de Autores Cristianos (BAC).

See Marco Roncalli, Giovanni XXIII: Angelo Giuseppe Roncalli; Una vita nella storia (Milan: Mondadori, 2006), 453 .

101 "The Oath against Modernism" was rescinded July 17, 1967, by the Congregation for the Doctrine of the Faith with the approval of Paul vi (r.1963-78).

For a description of the theological mentality of the Roman school, see de Lubac, Carnets du Council, 1:85-86.

See Michael Novak, The Open Church: Vatican II, Act II (New York: MacMillan Co., 1964): 52-70: "Non-historical orthodoxy encourages, or rather insists upon, the view that 'truth is unchanging.' But it does not seem to notice that languages change, that intellectual viewpoints and methods change, that new facts (even about ancient happenings) are discovered, that men's manner of understanding even the same sentences change. [...] 'Truth' may be unchanging, whatever it is when considered in the abstract. But, in the concrete, men's struggle to understand is not static and unchanging. Men's point of view, experience, conceptions, and language change. Men's grasp of 'truths' therefore changes, too" $(67)$.

Avery Dulles remarks that "Until Vatican Council II the neo-scholastic manuals of ecclesiology, in the tradition of Louis Billot and Joseph de Guibert, remained in full vigor" ("A Half Century of Ecclesiology," Theological Studies 50 [1989]: 419-42, here 419). Billot, first published in 1898 and reprinted many times almost to the eve of Vatican II, was an influential text, representative of this approach. Its themes were repeated with more 
papalist ecclesiology ${ }^{106}$ However, it would be incorrect to characterize Billot's ecclesiology as solely stressing "the monarchical character of papal authority almost to the exclusion of all other authority."107 Billot's teaching on the church also served to support the teaching on episcopal collegiality that was endorsed by the council in its Dogmatic Constitution on the Church. Mgr. Gérard Philips (1899-1972), one of its primary redactors appealed to Billot in support of this teaching: "The celebrated Cardinal Billot, who will certainly not be considered by anyone as a dangerous author, declares with solemnity in his treatise $D e$ ecclesia: "Nothing in the Catholic faith is more clearly established since the beginning than the dogma of the authority of the episcopate taken in its totality, either reunited in ecumenical council, or scattered throughout the world."'108

Prominent among the minority at the council was Archbishop Marcel Lefebvre (1905-91), a member of the Holy Ghost Congregation (the "Spiritans"), who served as a theological consultant to the council's Preparatory Commission. ${ }^{109}$ During the council, he was a founding member of the Coetus Internationalis Patrum (CIP) that opposed many of the council's salient teachings, especially "religious liberty," which they regarded as a heretical reversal of what previous popes had explicitly taught. ${ }^{110} \mathrm{He}$ was among the members of the cIP whose political-theological orientation had been decisively shaped by the counter-revolutionary, anti-liberal, anti-modernist mentality that he and his fellow seminarians had imbibed at the French National Seminary in Rome in the 1920 . ${ }^{111}$ Henri Le Floch (1862-1950), also a Spiritan, was a dominant

or less the same emphasis in all seminary textbooks on the subject" (What Happened at Vatican II, 156).

106 In his council notebooks, in support of this papalist position, de Lubac cited Billot's De ecclesia: "de Christi institutione fuisse ut ipsissima suprema potestas quae tota erat in uno Petro..." (1:584). See de Lubac, Carnets du Concile, 2:9. See O'Malley, What Happened at Vatican II, 156.

108 See Mgr. Philips, L'Église et sonmystère au II Concile du Vatican: Histoire, texte et commentaire de la Constitution Lumen gentium (Paris: Desclée de Brouwer, 1967), 1:279. Philips was citing from Billot's De ecclesia, 1:564.

109 Lefebvre served as superior general of the Spiritans from 1962 to 1968 when, at odds with fellow Spiritans who sought reform in response to the conciliar call for renewal, he submitted his resignation.

110 See Marcel Lefebvre, Un évêque parle: Écrits et allocutions, 2 vols. (Jarzé: DM Morin, 1976), 2:142. For example, the "Syllabus of Errors," issued by Pope Pius IX in 1864, had proscribed in its proposition $\#_{15}$ that "every man is free to embrace and profess that religion which, guided by the light of reason, he shall consider true."

111 Philippe J. Roy, "La Préhistoire du Coetus Internationalis Patrum: Une formation romaine, antilibérale et contre-révolutionnaire, in La Théologie catholique entre Intransigeance et Renouveau: La Réception des mouvements préconciliares à Vatican II, ed. Gilles Routhier, 
presence at the seminary during that era, having served as rector from 1904 until 1927 when Pope Pius XI ordered his removal. ${ }^{112}$ Le Floch, like many of his fellow Spiritans, was an avid AF supporter and a great friend of Billot. Though Billot never taught Lefebvre, he was closely tied to Le Floch and Billot regularly visited the French National Seminary where he was revered. ${ }^{113}$ Lefebvre remarked that Billot "was an eminent professor of the Gregorian, an extraordinary professor. His theological books are magnificent." He considered Billot "one of his masters." 114 What Lefebvre especially appreciated was that "[Billot] was an upright man: no compromise with error, firm in the truth and the battle against errors, liberalism, against modernism, like St. Pius x. He was a true disciple of St. Pius X."115

During the council, Pope Paul vi re-read Billot and other neo-Scholastic theologians whose intransigent defense of certain traditional Catholic positions such as the union of church and state were to be overturned by the council. He wanted to have a good grasp of the objections raised by Lefebvre and his allies. ${ }^{116}$ Jesuit church historian John O'Malley remarks that

The leaders of the minority worked within a narrower theological and cultural horizon. For their contemporaries they fit the stereotype of the proponents of "Roman theology," a theology heavily conditioned by canon law, indifferent to the problems raised by historical methods, and often hermeneutically naive. They had been schooled to disdain modern approaches to theology as passing novelties or, still influenced by Pascendi and Lamentabili, to attack them as dangerously subversive. They were the ultimate Ultramontanists. Of them the majority asked a great deal. By trying to convince them to go along with this or that position, the

Philippe J. Roy, and Karim Schelkens (Louvain-La-Neuve/Leuven: Universiteitsbibliotheek, 2011), 321-54. Roy remarks: "In sum, the history of the CIP is the concentrated history of all the battles of Catholic intransigence in the twentieth century" (322). [French original: "Bref l'histoire du Coetus Internationalis Patrum, c'est l'histoire condensée de tous les combats de l'intransigeance catholique au zoe siècle."].

See Eamon Duffy, Saints and Sinners: A History of the Popes, 2nd ed. (New Haven: Yale University Press), 338.

113 See Henri Le Floch, Le Cardinal Billot: Lumière de la théologie (Paris: Beauchesne, 1947).

114 See Gérard Leclerc, Rome et les lefebvristes: Le Dossier (Paris: Editions Salvator, 2009).

115 See Philippe J. Roy, "La Préhistoire du Coetus Internationalis Patrum," 338-39. See also Bernard Tissier de Mallerais, The Biography: Marcel Lefebvre, trans. Brian Sudlow (Kansas City: MO, 2004), 37 .

116 Yves Congar, My Journal of the Council, trans. Mary John Ronayne, O.P., and Mary Cecilly Boulding, O.P. (Liturgical Press: Collegeville, MN, 2012), 859. 
majority essentially asked them to adopt a new mind-set and a new value system and to affirm assumptions they feared and abhorred. ${ }^{117}$

After the council, Congar noted the déjà vu when he observed that Lefebvre's rejection of Vatican II and the popes associated with the council while appealing to pre-conciliar popes whose "anti-liberal" teachings, lifted from their historical context, he considered to be forever valid, mirrored the self-contradictory mentality of the AF recalcitrants who professed to be ultramontanes while resisting papal directives. Despite repeated Vatican efforts to reach out to him, Lefebvre's rejection of the council's "liberal" teachings finally led him and the Society of St. Pius X, the association he founded in 1970, into schism. ${ }^{118}$

\section{9}

\section{Conclusion}

In his study of twentieth-century theologians, the Dominican scholar Fergus Kerr wrote that "neglected, if not completely forgotten, Billot's work would need to be explored in any attempt to write a balanced and comprehensive history of modern Catholic theology."119 This study, while not a comprehensive exposition of Billot's theology, has highlighted Billot's contribution to the renewal of Thomistic studies that was officially authorized by Pope Leo. His influence as a Gregorian professor on future ecclesiastics and the wide diffusion and reprinting of his manuals guaranteed the influence of his teachings until the eve of the Second Vatican Council. However, while excelling as a speculative theologian, Billot's interest in historical theology was minimal at best.

\footnotetext{
117 O'Malley, What Happened at Vatican II, 293.

118 See Yves Congar, La crise dans l'Église et Mgr Lefebvre, 2nd éd. augmentée (Paris: Cerf, 1977), 14. Also see Florian Michel and Bernard Sesboüé, S.J., De Mgr Lefebvre à Mgr Williamson: Anatomie d'un schisme (Paris: Lethielleux/Desclée de Brouwer, 20o9). Twelve years before the definitive schism occurred in 1988, Lefebvre wrote to Henri de Lubac apropos of Vatican II: "What is called ecumenism, adaptation to the modern world, is by this mediation, the principles of modernism and liberalism which become those of the Church's pastors. This betrays the doctrine taught for two centuries in a continuous and explicit manner by the Sovereign Pontiffs" (Georges Chantraine and Marie-Gabrielle Lemaire, Henri de Lubac, vol. 4, "Concile et après-Concile, 196o-1991" [Paris: Cerf, 2013], 596).

119 Fergus Kerr, Twentieth-Century Catholic Theologians (Malden, MA: Blackwell Publishing, 2007), 10. Billot's work is not completely forgotten. See, for example, Alberto Cozzi, $L a$ centralità di Cristo nella teologia di L Billot (1846-1931) (Milan: Glossa, 1999), 24; and Giancarlo Vergano, Ragione e fede, dalla distinzione all'armonia: Una ricerca... non dimenticando L. Billot (Siena: Edizioni Cantagalli, 2019).
} 
Belatedly, as mentioned above, Billot acknowledged in a private letter to Jules Lebreton (1873-1956) that Lebreton's study of the historical development of the doctrine of the Trinity had opened his eyes to the value of historical study.

Billot played a crucial role in the church's anti-modernist campaign. The Modernist crisis was a severe trial for the church, especially during the pontificate of Pius x. Undoubtedly there were anti-modernist "witch hunts" that caused great distress. ${ }^{120}$ Nevertheless, the historicism of Alfred Loisy and other scholars did pose a significant threat to the integrity of the church's faith. ${ }^{121}$ In his work that rebuts an "evolutionary" understanding of dogma, Billot especially targeted Loisy. Questions regarding the nature and understanding of revelation, dogma, and tradition are still topics of controversy in the contemporary church. One could fruitfully revisit Billot's criticisms of Loisy.

In retrospect, the most scandalous aspect of Billot's ecclesiastical career was his affinity for the political movement of Action Française. He was not alone among French Catholics and Vatican ecclesiastics who viewed a Catholic alliance with AF as a viable political to reverse the anti-clerical politics of the French Third Republic. Most Jesuits of his generation were "monarchist," though not all shared Billot's "integralist" mentality and many were scandalized by a Catholic alliance with AF. Billot considered Maurras a forceful critic of the liberal individualism that was harming the church's "eldest daughter." However, Billot was not an uncritical admirer and he privately communicated his abhorrence of the paganism in Maurras's writings. And though disagreeing with Pius XI's decision to forbid Catholic association with AF, he reconciled himself to retirement as a simple religious of the Society of Jesus. ${ }^{122}$

See my forthcoming article on the Modernist crisis and the tragic relationship between Pope Pius x and Jesuit Superior General Wernz. 231-64.

122 Murel Vogel, S.J. (1904-99) personally related to me that when he was a young scholastic studying in Rome in the late 1920s, he had met Billot who impressed him with his serenity of spirit. 